\title{
The Madurese Women's Resilience in the Face of Hizbut Tahrir Indonesia (HTI) in Madura
}

\author{
A Khatib ${ }^{1}$, H M A Hasan ${ }^{2}$, A Ishomudin ${ }^{3}$ \\ Institut Ilmu Keislaman Annuqayah (INSTIKA) Guluk-Guluk Sumenep; ${ }^{1,2}$ \\ Institut Agama Islam Negeri (IAIN) Madura $^{3}$ \\ \{mas.khotib@gmail.com ${ }^{1}, \underline{\text { m.afif.hasan@gmail.com }}$, ibnuishom.ai@gmail.com ${ }^{3}$ \}
}

\begin{abstract}
This article discusses the dynamics of Islam and diversity in Indonesia as a recent and exciting phenomenon. It relates to the global Islamic movement or "transnational Islamic movement," especially Hizb Tahrir Indonesia (HTI), which is developed and gaining followers in Indonesia, including in Madura. Madurese women react to this phenomenon by building resilience. The research demonstrated that women are also interested in and concerned about religious issues, not only those related to timing-deeper (kitchen-stove), marginalization, or domestic submission. Does this paper attempt to answer the questions what are the resilience among the Madurese women against Hizb ut-Tahrir Indonesia (HTI)? And how and why they build resilience in the face of this Islamist group. This article uses a social anthropology approach based on the theory of resilience. The study found that the Madurese women made use of their local wisdom in building their resilience. The process of building resilience arises from their awareness of the potential chaos and disorder due to the HTI strategy. The Madurese women also believed that the Islamist group will likely cause social divisions, destroy the nation-state of Indonesia. They choose resilience, rather than violence because the latter is considered irrelevant to Islam and the doctrine of ahl al-sunah wa al-jamaah.
\end{abstract}

Keywords: Resilience, Madurese Women, HTI, Madura.

\section{Introduction}

The term "Transnational Islam" is still problematic [1]. However, HTI, as Masdar Hilmy said, falls into the category. Although HTI is embedding with the word "Indonesia", it is still a transnational organization [2], [3]. HTI's ideology as an Islamist movement is not in line with Indonesian Islamic orthodoxy [4], [5] although it has different points from the MMI (Majlis Mujahidin Indonesia) and FPI (Front Pembela Islam). The transnational group spreads a political agenda, although they do not admit it [2], by using many media. ${ }^{1}$

Indonesia has been one of the transnational Islamic targets, including Hizbut Tahrir Indonesia (HTI). However, this movement was challenged by the santris community originating from many different numbers of Islamic educational institutions. ${ }^{2}$ The Madurese women ${ }^{3}$ and santris are involved in the challenge by taking a strategy of resilience. It is interesting to see this development since the Madurese women have been known very calmly, compliant, and less concerned about religious issues.

${ }^{1}$ Masdar Hilmy, Akar-Akar Transnasionalisme Islam Hizbut Tahrir Indonesia (HTI), Jurnal ISLAMICA, hlm. 5-6.

2 Azyumardi Azra, Pendidikan Islam di Era Globalisasi: Peluang dan Tantangan, makalah dalam Seminar Nasional "Pesantren dan Globalisasi" di Institut Ilmu Keislaman Annuqayah (INSTIKA), pada 20 December 2014, hlm. 9

${ }^{3}$ Zamakhsyari Dhofier, Tradisi Pesantren: Studi tentang Pandangan Hidup Kyai (Jakarta: LP3ES, 1994), hlm. 21. Lihat juga M. Dawam Raharjo, Pesantren dan Pembaharuan (Jakarta: LPES, 1974), hlm. 40. Lihat Ibrahim bin Ismail, Syarhu Ta'lîm al-Muta'allim, (Jakarta: Dar AlKutub Al-Islamiyah, 2007), hlm. 35-37. 
There are two reasons why it is interesting to examine resilience among the Madurese women. The first is that although most of them are farmers [6], they have a concern about contemporary religious issues. They are involved in starting the movement by doing resilience against HTI. The Madurese women demonstrated evident resilience, which is contrary to their characteristics as Madurese. Does this paper attempt to answer the questions what are the resilience among the Madurese women against Hizb ut-Tahrir Indonesia (HTI)? And how and why they build resilience in the face of this Islamist group.

Some scholars have done similar research, such as [7]-[11]And [1]. However, none of them focuses on the resilience of Madurese women, particularly in facing the transnational group. Therefore, this study will fill "the gap" that exists in those previous researchers.

\section{Method}

This study uses a social anthropology approach by utilizing a resilience theory. The data collected through in-depth interviews [12], participant observation [13] and document researches [14]. The data were analyzed using a descriptive method as proposed by Miles \& Huberman [15], which include the phases of data reduction, data display, and conclusion.

Resilience is the ability to adapt positively to the challenges [16]. Resilience is a trait or process to get back from something, go beyond, survive, or adapt successfully to a wide variety of life challenges. In the context of the spread of the ideology of HTI, resilience is the ability to avoid and prevent the influence of HTI.

In the context of the spread of the ideology of HTI, resilience in this research refers to women's ability to deflect or prevent people from spreading the ideology and teachings of HTI, as well as respond quickly to those who are entangled. The hazard (danger, threat) is still there, but it has no significant effect on those who have been powerfully resilient.

\section{Result and Discussion}

HTI intervention to Madurese women seemed to be unsuccessful because they have their resilience. The research site included three or several districts, including Sumenep (Gapura, Kota, Saronggi, Bluto), Pamekasan (Kota, Kadur, Pasean), and Bangkalan (Telang Village in Kamal). In Sumenep, HTI is gaining ground rapidly. In Gapura, HTI activists are frequently invited to attend routine Islamic discussions for which they never asked fees or pick-ups. Young people who still have limited knowledge of Islamic teachings seem to be sympathetic to this group. As a result, HTI activists openly declared their identity in gatherings (kompolan). In response to this, resilience takes the form of preacher's selection, strengthening of the Asy'ariyah faith by the Aswaja Team of East Java. Resilience is chosen to avoid physical violence [16].

Resilience in Kota is done by conducting PKP (Pendidikan Kader Penggerak), and social media. Resilience is also done by mainstreaming a discussion of classical books that teach a moderate understanding of Islam, such as Al-Husunul Hamidiyyah or Al-Hikam by Ibn Ata Allah As-Sakandari, or Misykatul Anwar led by Thaifur Ali Wafa. The presence of the Boarding School Alumni Association (Persatuan Alumni Pondok Pesantren) has been also strengthened to counter the HTI ideology. Public recitation and Islamic holidays are also celebrated in the city center. Online and live streaming religious discussions and groups are also frequently established, such as al-Muqtathofat li Ahlil Bidayat by KH. Marzuki Mustamar, and Radio Gema Sumekar (RGS), RRI, and Nada FM. Muslim women leaders, such as $\mathrm{Ny}$. $\mathrm{Hj}$. Wafiqah Jamilah (from BatangBatang subdistrict), $\mathrm{Ny}$. $\mathrm{Hj}$. Na'imah (Batang-Batang subdistrict), and $\mathrm{Ny}$. $\mathrm{Hj}$. Anis (Lenteng subdistrict) have been actively doing resilience through radios.

Resilience in Bluto is done through counteracting the logic of wearing the niqab, as most of the students in boarding schools believe, reciting the Book of Al-Farqu Baynal Firoq Abdul Qahir by Abu Mansur ibn Tahir al-Baghdadi, and intensifying Muslim kompolan, such as Thariqoh Naqsabandiyah. While in Saronggi, kompolan of Muslim women become more creative, where they strengthened moderate ideology and optimized small sword artisan, or kompolan of Sarwah and Barzanji. 
Women in Kota, Pamekasan, are also involved in resilience against HTI. Through kompolan of Fatayat they repeatedly announce the independence heroes, in the downtown mosque Masjid AshShuhada. They also frequently celebrate Prophet Muhammad's Birthday and other typical activities of moderate Islam. They recite the Book of Riyadus Sholihin by Imam Nawawi, and the women activists loudly sound the slogan "NKRI HARGA MATI".

In Kadur, women Islamic discussion is more active, facilitated by kompolan Fatayat, who socialize the doctrines of aswaja vis-a-vis HTI. While in Pasean, the youth kompolan, teachers in schools, and Nyai Langgar, are promoting intensively Islam washatiyyah and asking for debate with the new transnational ideologists.

Another form of resilience in Telang village, Kamal, Bangkalan is that women in a mosque select their own candidates for mosque's takmir and the Qur'an teachers. The youths are also involved in village governance initiating religious activities and community, which aim to strengthen national ideology. Women's complaints on HTI is gaining ground rapidly. Religious activities, such as diba'an, barzanjian, and Yasinan are intensified. Women in Bangkalan consider HTI as a serious threat to which they respond in a resilient manner.

\section{Conclusion}

The Madurese women's resilience in the face of HTI included some strategies and activities. They provided information about HTI quickly through active referrals. They also strengthen women kompolan (gatherings) involving mothers and young women, and the alumni network of boarding schools (pesantrens). They intensified off-line and online discussion studying the classical book of moderate Islam (Aswaja), and promoted cultural nuances of Islam wasathiyah. The roles of NU at the leadership and individual levels are also pertinent. Through their social gatherings and education institutions, they escalated studies on Sufism and conducted diba'an or barzanji traditions more frequently. They also keep being alert of the spread of any other new isms by choosing selectively new religious preachers or teachers.

The formation process of resilience are preceded by an awareness among the Madurese women to prevent potential chaos and uproar because of HTI presence. They are involved in a number of resilient activities because the intervention of HTI will likely cause chaos among society. They also consider HTI a threat to the nationalism of Indonesia. They choose resilience because violence against the intervention of HTI, despite its propaganda, is justified by Islam of Ahlus Sunnah Wal Jamaah. Therefore, resilience is the best strategy for them in countering the transnational ideology of HTI.

\section{References}

[1] M. Hilmy, "Akar-Akar Transnasionalisme Islam Hizbut Tahrir Indonesia (HTI)l," in Jurnal ISLAMICA Studi Keislaman, 2011, vol. 6, no. 1, pp. 1-3.

[2] A. S. Maarif, I. Ali-Fauzi, and S. R. Panggabean, Politik Identitas dan Masa Depan Pluralisme Indonesia. Jakarta: PUSAD, 2010.

[3] N. Madjid, Bilik-Bilik Pesantren. Jakarta: Paramadina, 1997.

[4] A. Azyumardi, Sejarah Pertumbuhann Pekembangan Lembaga-Lembaga Pendidikan Islam Di Indonesia. Jakarta: Grasindo, 2001.

[5] A. Azra, "Pendidikan Islam di Era Globalisasi: Peluang dan Tantangan," in makalah dalam Seminar Nasional di Institut Ilmu Keislaman Annuqayah (INSTIKA), 2014, p. 9.

[6] A. R. Mien, Manusia Madura. Yogyakarta: Pilar Media, 2007.

[7] P. Dirdjosanjoto, Memelihara Umat: Kiai Pesantren-Kiai Langgar di Jawa. Yogyakarta: LKiS, 1999. 
[8] Kuntowijoyo, Perubahan Sosial Dalam Masyarakat Agraris Madura 1850-1940. Jogjakarta: Mata Bangsa, 2002.

[9] M. Tahir, "Pergumulan Hukum Islam dan Budaya Sasak: Mengarifi Fiqih Islam Wetu Telu," “ISTIQRO” J. Penelit. Islam Indones., vol. 6, no. 1, p. 180, 2007.

[10] M. E. Saputro, Kiai Langgar and Klebun: A Study on Contestation Between Cultural Brokers in a Non-Pesantren Village in Madura, Indonesia. Yogyakarta: Graduate School Gadjah Mada University, 2009.

[11] S. Rijal, "Menarik Anak Muda Muslim: Studi terhadap Sistem Rekrutmen Hizbut Tahrir Indonesia di Makassar, Sulawesi Selatan"," in makalah pada Annual Conference on Islamic Studies (ACIS) di Banjarmasin, 1 - 4 November, 2010, p. 742.

[12] S. Hadi, Metodologi Research. Yogyakarta: Yayasan Penerbitan Fakultas Psikologi UGM, 1987.

[13] W. Surakhmad, Pengantar Metodologi Ilmiah. Bandung: Tarsito, 1982.

[14] Tim, Ensiklopedi Indonesia. Jakarta: Penerbit Ikhi Baru Van Hauve, 1980.

[15] L. J. Meleong, Metode Penelitian Kualitatif. Jakarta: Rineka Cipta, 2012.

[16] W. A. dkk. Ghafur, "Resilience Perempuan dalam Bencana Alam Merapi: Studi di Kinahrejo Umbulharjo Cangkringan Sleman Yogyakarta,” J. Welf., vol. 1, no. 1, p. 46, 2012. 